------ Raf. J. Sci., Vol. 24, No.5 pp. 42-51, 2013------

\title{
Spectrophotometric Determination of Teicoplanin via Coupling with Diazotized p-Nitroaniline
}

\author{
Nabeel S. Othman \\ Nabil H. Othman \\ Department of Chemistry \\ College of Science \\ University of Mosul
}

(Received 9/10/2012 ; Accepted 28/1/2013)

\begin{abstract}
A new, simple and sensitive spectrophotometric method was described for the determination of teicoplanin as a pure material and in pharmaceutical formulation. The method is based on the coupling of teicoplanin with diazotized p-nitroaniline in alkaline medium. The dye shows an absorption maximum at $490 \mathrm{~nm}$ and obeys Beer's law over a range of 2 to $80 \mu \mathrm{g} . \mathrm{ml}^{-1}$ of teicoplanin. The molar absorptivity of the coloured azo dye is $2.8 \times 10^{4} 1 . \mathrm{mol}^{-1} \mathrm{~cm}^{-1}$. The relative standard deviation does not exceed $2.7 \%(\mathrm{n}=5)$. The azo dye formed is stable for 60 minutes. The method was applied successfully to the assay of teicoplanin in pharmaceutical preparation (injection).
\end{abstract}

Keywords: Teicoplanin, determination, spectrophotometry, diazo-coupling.

القدير اللمي اللتيكولانين بلستخدلم الفترلنمع بارا - ناليترو لنيلنن المؤنوت

\section{الملغ}

مم توضبحطريقةطيفيه جدية وبسيطة ومشلسة لقنير التيكوبلانين بوصفه مادة قية وفي مستحضره الصيدلاني (القنة)، وتعتمد الطريقة على تفاعل الاقتران الازوي بين التيكوبلانين والكلثف المؤزوت بارا

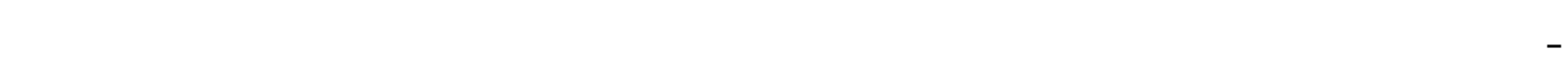

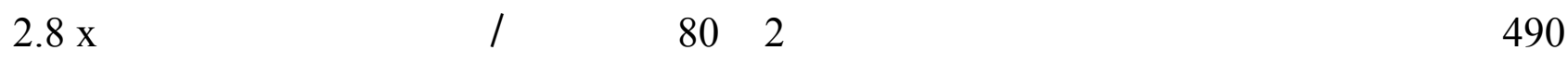

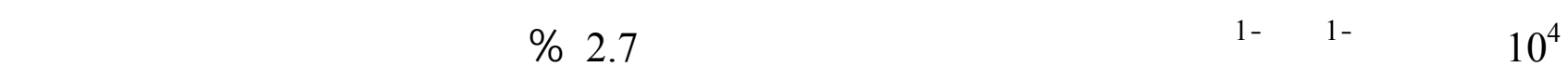
الفترة 60 دقيقة، وطقت الطريقة بنجاح على المستحضر الصيدلاني (الحقنة).

\section{INTRODUCTION}

Teicoplanin is an antibiotic used in the prophylaxis and treatment of serious infection caused by gram-positive bacteria, its mechanism of action is to inhibit the bacterial cell wall synthesis (Wilson et al., 1994). A recent research showed that in 2005 an estimation of 18,650 in hospital deaths was due to methicillin resistant Staphylococcus aureus infections in the united states (Klevens et al., 2007). Teicoplanin is a glycopeptide antibiotic having a good activity against MRSA (Barna et al., 1984).Teicoplanin is not official yet neither in 
the United States Pharmacopeia (USP 35) nor B.P. 2009. Teicoplanin (TARGOCID, marketed by Sanofi Aventis Ltd) is actually a mixture of several compounds, five major (named teicoplanin A2-1 through A2-5) and four minor (named teicoplanin RS-1 through RS-4). All teicoplanins share the same glycopeptide core, termed teicoplanin A3-1 - a fused ring structure to which two carbohydrates (mannose and N-acetylglucosamine) are attached. The major and minor components also contain a third carbohydrate moiety - $\beta$ D-glucosamine - and differ only by the length and conformation of a side-chain attached to it. The structures of the teicoplanin core and the side-chains that characterize the five major teicoplanin compounds are shown in (Fig.1) (Wikipedia).
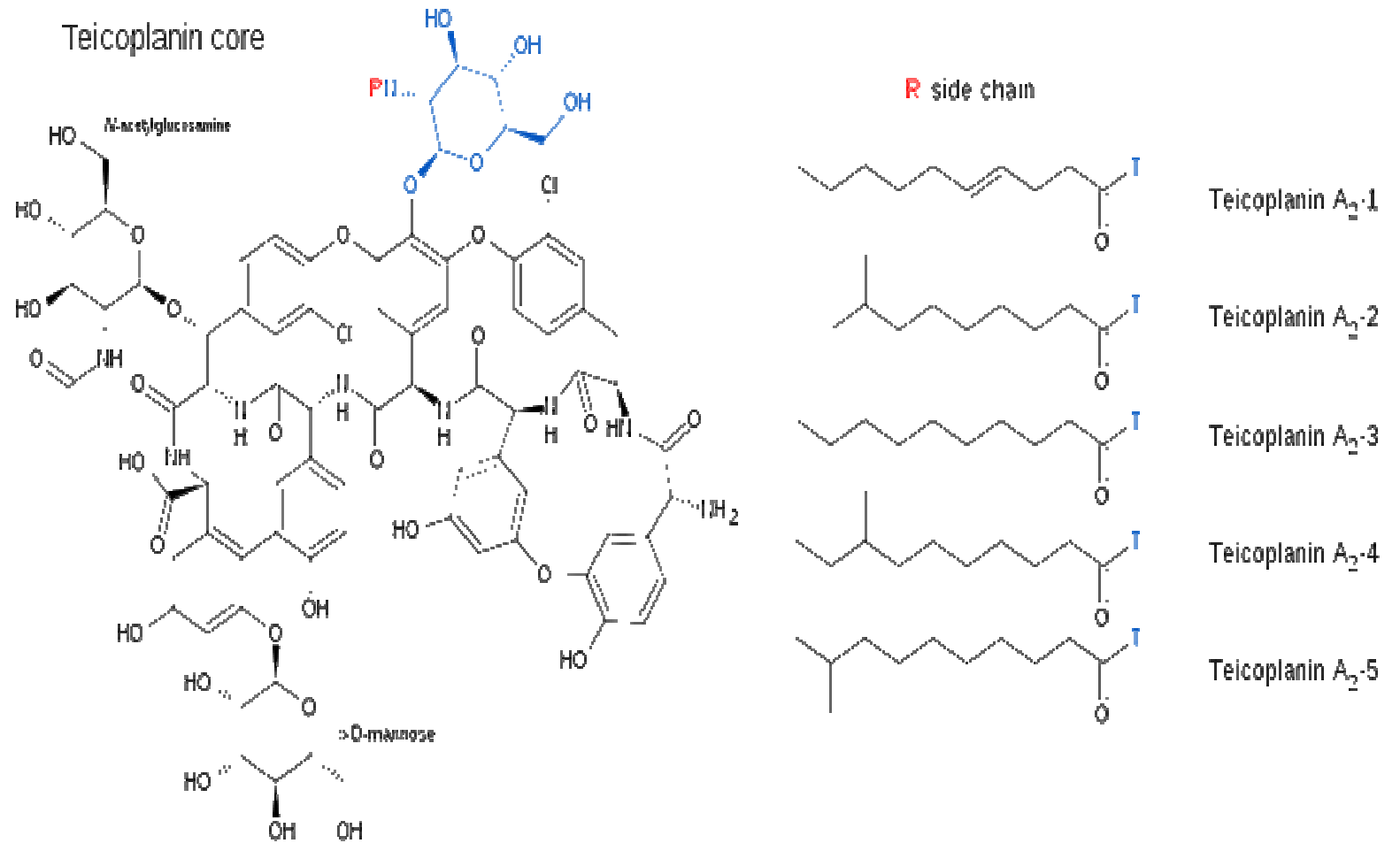

Fig. 1: Teicoplanin core structures

The reports found in the literature for teicoplanin determination concentrate on chromatographic methods (Cociglio et al., 1998; Taylor et al., 1991; McCann et al., 2002; Hanada et al., 2005; Joos et al., 1987), fluorescence (White et al., 1996 ; Cox et al., 1993), capillary electrophoresis (Taylor et al., 1999) and solid phase extraction and micellar electro kinetic chromatography (Bourget et al., 1997).

To the best of our knowledge, no visible spectrophotometric method is available for the quantification of teicoplanin in pharmaceutical preparations. This paper describes a visible spectrophotometric method based on the diazo-coupling reaction of teicoplanin with diazotized p-nitroaniline. 


\section{Apparatus}

\section{EXPERIMENTAL}

A Shimadzu model UV - 160 UV / Vis spectrophotometer and Agilent UV-DAD 8453 with $1 \mathrm{~cm}$ matched quartz cells were used for all measurements of absorbance and for the absorption spectra.

\section{Reagents}

All chemicals used in this study are analytical grade reagents, and distilled water was used for preparing the reagent solutions.

Teicoplanin solution $200 \mu \mathrm{g} \cdot \mathrm{ml}^{-1}$ (working standard) was prepared by dissolving $0.02 \mathrm{~g}$ of teicoplanin in distilled water and further added to $100 \mathrm{ml}$, in a volumetric flask. Diazotized p-nitroaniline $(0.01 \mathrm{M})$ was prepared by dissolving $0.138 \mathrm{~g}$ of p-nitroaniline in $20 \mathrm{ml}$ of $\mathrm{HCl}(1 \mathrm{M})$ followed by further dilution to $80 \mathrm{ml}$ with distilled water. The mixture was boiled until all p-nitroaniline was dissolved then the solution was transferred to a $100 \mathrm{ml}$ volumetric flask and cooled to $(0-5){ }^{\circ} \mathrm{C}$ in an ice-bath, a $0.069 \mathrm{~g}$ of sodium nitrite was added then stirred vigorously, after 5 minutes the solution was made up to $100 \mathrm{ml}$ with cooled distilled water and stored in an amber bottle in a refrigerator. Sodium hydroxide solution $(1 \mathrm{M})$ was prepared by dissolving $4 \mathrm{~g}$ of $\mathrm{NaOH}$ in distilled water and further diluted to $100 \mathrm{ml}$ in a volumetric flask.

\section{Recommended procedure and calibration graph}

An aliquot of the sample solution containing 20-800 $\mu \mathrm{g}$ of teicoplanin was transferred into a series of $10-\mathrm{ml}$ volumetric flasks. To this solution, $1 \mathrm{ml}$ of diazotized p-nitroaniline $(0.01 \mathrm{M})$ and $0.5 \mathrm{ml}$ of sodium hydroxide solutions $(1 \mathrm{M})$ were added. The solution was shaken thoroughly for $1 \mathrm{~min}$ to allow the diazo-coupling reaction to be completed, then the contents were diluted to the mark with distilled water and mixed well. After $5 \mathrm{~min}$, the absorbance of the coloured azo dye was measured at $490 \mathrm{~nm}$ against the reagent blank which was prepared in a similar way but without the addition of teicoplanin. The calibration graph as shown in (Fig. 2) was linear over the range of 2-80 $\mu \mathrm{g} \cdot \mathrm{ml}^{-1}$. The apparent molar absorptivity referred to teicoplanin has been found to be $2.8 \times 10^{4} 1 . \mathrm{mol}^{-1} \mathrm{~cm}^{-1}$

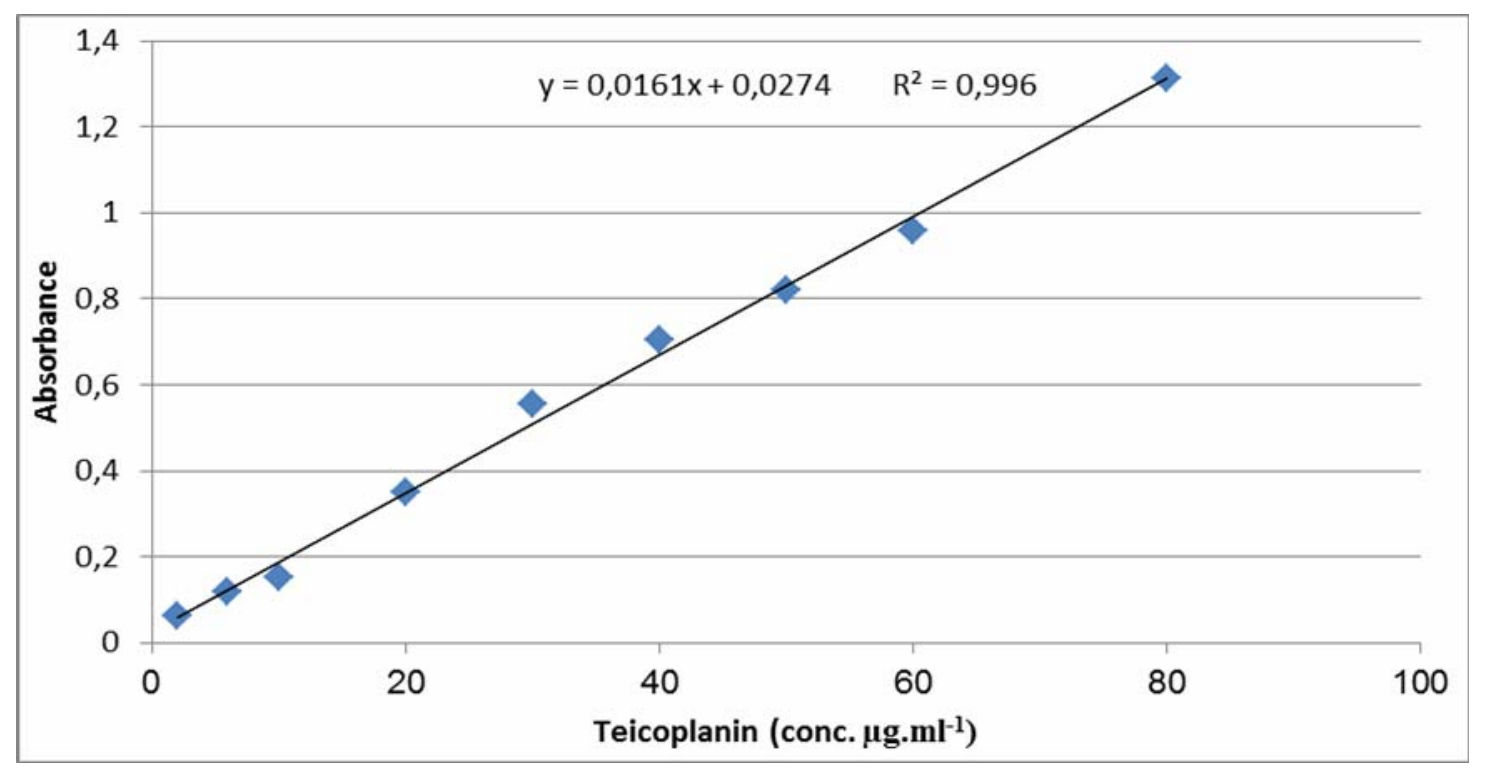

Fig. 2: Calibration graph of teicoplanin determination using the proposed method. 


\section{Determination of teicoplanin in injection}

After mixing the contents of two injections (Targocid), an accurately weighed amount of a powder equivalent to $0.02 \mathrm{~g}$ teicoplanin was dissolved in distilled water and further diluted to $100 \mathrm{ml}$ in a volumetric flask. A suitable aliquot of solution was taken and the recommended procedure was followed to analyze the drug.

\section{RESULTS AND DISCUSSION}

The method involves the coupling reaction between teicoplanin with diazotized p-nitroaniline in an alkaline medium to give a deep orange coloured azo dye. Two steps are involved in the reaction that produces the colored dye. The first step included the preparation of diazotized p-nitroaniline as mentioned before while the second step involved the coupling of the diazonium ion with teicoplanin in an alkaline medium to form an azo dye, which it is stable for a suitable period of time (about 60 mins).

The steps involved are shown in Scheme 1:

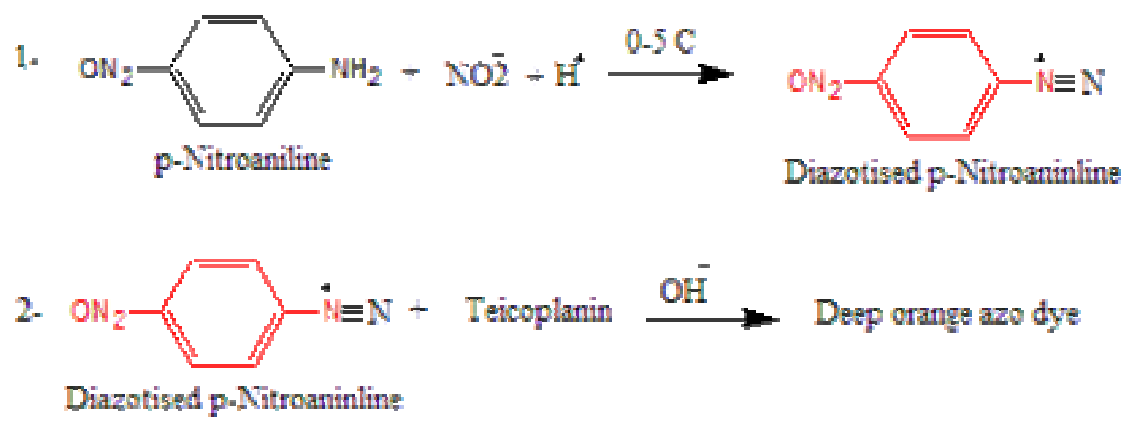

\section{Scheme 1: Steps of the main reactions}

The effect of various variables on the color development of the azo dye formed from the reaction of teicoplanin with diazotized p-nitroanline was investigated and the optimum conditions have been selected.

\section{Effect of reagent concentrations}

It was observed from the results of Table (1), that $2 \mathrm{ml}$ of $(0.01 \mathrm{M})$ solution of diazotized p-nitroaniline was required for a complete coupling according to the highest intensity of the formed azo dye and the value of determination coefficient $\left(\mathrm{R}^{2}\right)$. This volume was recommended in the subsequent experiments.

Table 1: Effect of diazotized p-nitroanline reagent on absorbance

\begin{tabular}{|c|c|c|c|c|c|c|c|}
\hline \multirow{2}{*}{$\begin{array}{c}\text { Reagent } \\
\text { volume }(\mathrm{ml})\end{array}$} & \multicolumn{6}{|c|}{ Absorbance / $\mu \mathrm{g}$ of teicoplanin in $\mathbf{1 0} \mathrm{ml}$} & \multirow[t]{2}{*}{$\mathbf{R}^{2}$} \\
\hline & 50 & 100 & 200 & 300 & 400 & 600 & \\
\hline 0.25 & 0.031 & 0.059 & 0.110 & 0.130 & 0.186 & 0.215 & 0.9534 \\
\hline 0.5 & 0.040 & 0.085 & 0.102 & 0.175 & 0.219 & 0.223 & 0.8785 \\
\hline 1.0 & 0.055 & 0.128 & 0.247 & 0.313 & 0.362 & 0.439 & 0.9273 \\
\hline 2.0 & 0.121 & 0.210 & 0.318 & 0.514 & 0.609 & 0.816 & 0.9865 \\
\hline 3.0 & 0.091 & 0.154 & 0.223 & 0.342 & 0.370 & 0.415 & 0.9006 \\
\hline
\end{tabular}




\section{Effect of Base}

The effect of different bases ( $1 \mathrm{ml}$ of $1 \mathrm{M}$ of each base was added) on the absorbance of the azo dye was studied (Table 2).

\section{Table 2: Effect of base}

\begin{tabular}{|l|l|l|l|l|}
\hline $\begin{array}{l}\text { Base used } \\
(\mathbf{1 M}) \text { soln. }\end{array}$ & $\boldsymbol{\lambda}$ max of Blank & $\boldsymbol{\lambda}$ max of sample & Absorbance & Color contrast (nm) \\
\hline $\mathrm{NaOH}$ & 404 & 490 & 0.314 & 86 \\
\hline $\mathrm{NaHCO}_{3}$ & 384 & 423 & 0.257 & 39 \\
\hline $\mathrm{Na}_{2} \mathrm{CO}_{3}$ & 401 & 407 & 0.442 & 6 \\
\hline
\end{tabular}

The results in Table 2 indicate that the reaction needs a strong alkaline medium, and $0.5 \mathrm{ml}$ of $\mathrm{NaOH}$ (Table 3) was recommended in the subsequent experiment due to the highest intensity and value of the color contrast which was obtained for the formed azo dye.

Table 3: The optimum amount of sodium hydroxide

\begin{tabular}{|l|l|l|l|l|}
\hline $\begin{array}{l}\text { ml of } \mathrm{NaOH}(\mathbf{M}) \\
\text { soln. }\end{array}$ & $\mathbf{0 . 2 5}$ & $\mathbf{0 . 5}$ & $\mathbf{1 . 0}$ & $\mathbf{2 . 0}$ \\
\hline Absorbance & 0.102 & 0.349 & 0.324 & 0.229 \\
\hline
\end{tabular}

\section{Effect of surfactant}

The effect of surfactants with different orders of addition on the absorbance was studied; the addition of $3 \mathrm{ml}$ of each of cetylpyridinum chloride $\left(\mathrm{CPC}, 1 \times 10^{-3} \mathrm{M}\right)$, sodium dodecyl sulphate (SDS, $\left.1 \times 10^{-3} \mathrm{M}\right)$ and Triton $\mathrm{X}-100(1 \%)$ was examined. The investigations showed that there is no remarkable change in the absorbance of both SDS and Triton X-100. On the other hand, CPC gives a turbid solution, therefore, they were omitted in this study.

\section{The stability of the formed azo dye}

The stability of the formed colored azo dye was investigated under the optimum conditions recommended for the determination of teicoplanin Table (4). 
Table 4: Stability of azo dye

\begin{tabular}{|l|l|l|l|}
\hline \multirow{2}{*}{ Time, min } & \multicolumn{3}{|l|}{ Absorbance $/ \boldsymbol{\mu g} \cdot \mathbf{m l}^{-\mathbf{1}}$ of teicoplanin * } \\
\cline { 2 - 4 } & $\mathbf{1 0}$ & $\mathbf{2 0}$ & $\mathbf{4 0}$ \\
\hline $05: 00$ & 0.156 & 0.358 & 0.725 \\
\hline 10:00 & 0,156 & 0.358 & 0.725 \\
\hline 15:00 & 0.156 & 0.357 & 0.725 \\
\hline $20: 00$ & 0.155 & 0.358 & 0.725 \\
\hline $25: 00$ & 0.153 & 0.358 & 0.724 \\
\hline $30: 00$ & 0.152 & 0.358 & 0.724 \\
\hline $35: 00$ & 0,152 & 0.357 & 0.724 \\
\hline $40: 00$ & 0.152 & 0.358 & 0.724 \\
\hline $45: 00$ & 0.152 & 0.357 & 0.723 \\
\hline $50: 00$ & 0.151 & 0.358 & 0.722 \\
\hline $55: 00$ & 0.151 & 0.360 & 0.721 \\
\hline $60: 00$ & 0.150 & 0.358 & 0.721 \\
\hline Deviation & $4.0 \%$ & $0.6 \%$ & $0.6 \%$ \\
\hline
\end{tabular}

*Final concentration.

The results in Table 4 indicate that the coloured azo dye develops immediately and the absorbance remains maximum and constant for at least 60 minutes.

\section{Final absorption spectra}

The absorption spectra of teicoplanin-p-nitroanline azo dye and its corresponding reagent blank are shown in (Fig. 3). The azo dye shows maximum absorption at $490 \mathrm{~nm}$ in contrast to the reagent blank which shows maximum absorption at $404 \mathrm{~nm}$.

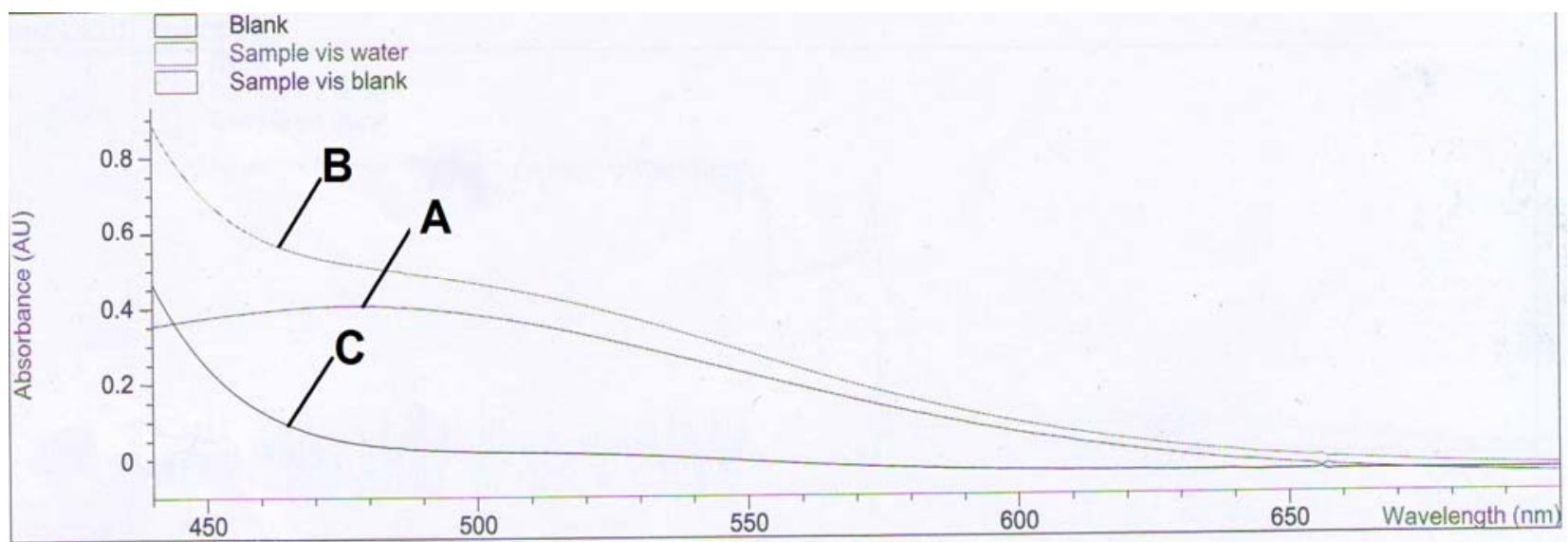

Fig. 3: Absorption spectra of $200 \mu \mathrm{g}$ teicoplanin treated according to the recommended procedures and measured against (A) blank (B) distilled water and (C) blank against distilled water.

\section{Nature of azo dye}

The result of appling Job's and mole-ratio methods(Hargis, 1988) indicate that the azo dye has a compostion of 1:1 teicoplanin [TCP] to diazotized p-nitroanline [PNA]. (Fig. 4 and 5). 


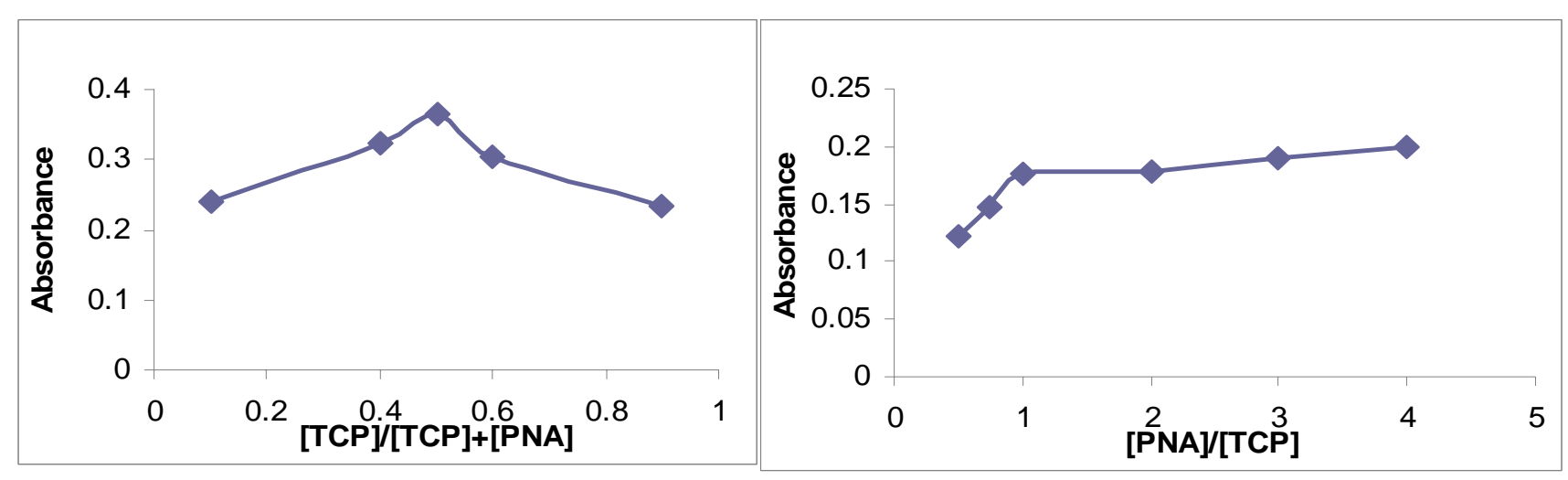

Fig. 4: Job`s method plot

Fig. 5: Mole ratio method plot

According to the literature reports (Al-abbasi, 2009; Othman and Thamer, 2009) which indicate that the more refined position for diazo coupling reaction was para position therefore, the suggested structure was as shown below (scheme 2).

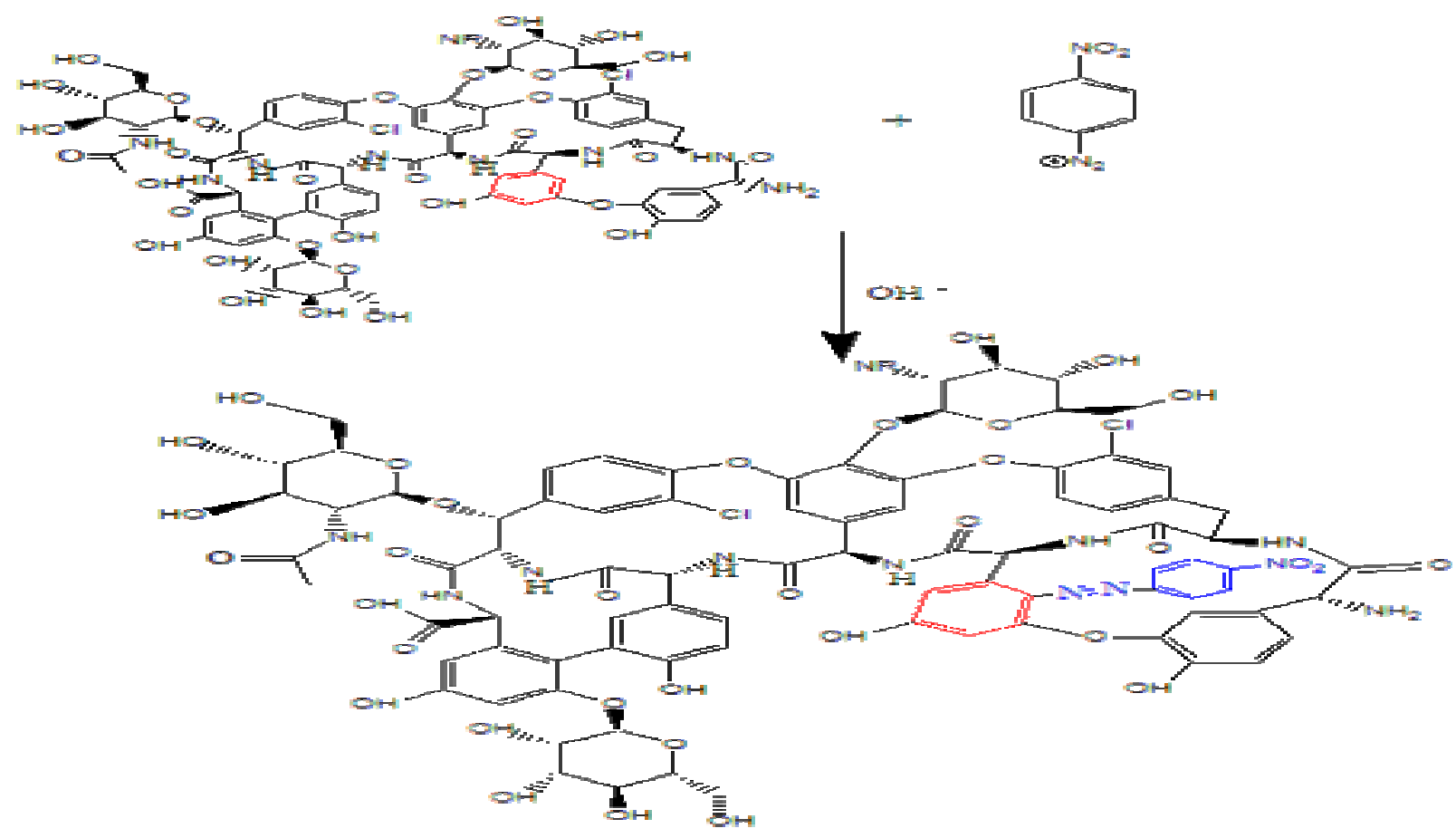

Scheme 2: Suggested structure of the dye formed

\section{Analytical Data}

Beer's law was obeyed in the range 2 to $80 \mu \mathrm{g} \cdot \mathrm{ml}^{-1}$ of teicoplanin (Fig. 3). The molar absorptivity $(\mathrm{C})$ and Sandells sensitivity for the colour of azo dye were found to be $2.8 \times 10^{4} 1$ $\mathrm{mol}^{-1} \mathrm{~cm}^{-1}$ and $0.0625 \mu \mathrm{g} . \mathrm{cm}^{-2}$, respectively. The reproducibility of the method was tested, the results showed no more than $2.7 \%$ changes in the absorbance during the determination of a fixed amount of teicoplanin within the applicable range, were observed. 


\section{Effect of interferences}

In order to assess the possible analytical applications of the present proposed method, the interfering effect of foreign substances on the determination of $200 \mu \mathrm{g}$ of teicoplanin is shown in Table 5. It is evident from the table that the proposed method has good selectivity.

Table 5: Interfrernceces Effect

\begin{tabular}{|l|c|c|c|}
\hline \multirow{2}{*}{ Excipient } & \multicolumn{3}{|c|}{$\begin{array}{c}\text { Recovery* \% of } 200 \boldsymbol{\mu g} \text { TCP/ } \\
\mu g \text { of foreign compound added }\end{array}$} \\
\cline { 2 - 4 } & 100 & 500 & 1000 \\
\hline Lactose & 100.26 & 98.54 & 98.32 \\
\hline Dextrose & 100.59 & 99.92 & 99.93 \\
\hline Sodium benzoate & 98.49 & 97.72 & 96.88 \\
\hline Starch & 100.42 & 100.80 & 101.57 \\
\hline
\end{tabular}

*Average of five determinations.

\section{Application of the method}

The proposed method has been successfully applied to the determination of teicoplanin injection dosage form. The results in Table 6 indicate that the suggested method has a good precision, and the RSD \% is not more than $2.7 \%$.

\section{Table 6: Appliction of the prposed method}

\begin{tabular}{|c|c|c|c|}
\hline $\begin{array}{c}\text { Pharmaceutical } \\
\text { preparation }\end{array}$ & $\begin{array}{c}\text { Amount taken } \\
(\boldsymbol{\mu g} \mathbf{g})\end{array}$ & $\begin{array}{c}\text { Recovery } \\
(\mathbf{\%})\end{array}$ & $\begin{array}{c}\text { RSD } \\
\mathbf{( \% )}\end{array}$ \\
\hline \multirow{2}{*}{$\begin{array}{c}\text { Teicoplanin Injection } \\
\text { (Targocid) }\end{array}$} & 100 & 99.1 & 2.67 \\
\cline { 2 - 4 } & 200 & 101.9 & 1.67 \\
\cline { 2 - 4 } & 400 & 99.4 & 1.36 \\
\hline
\end{tabular}

The validity of the method was confirmed by applying the standard addition procedure (Fig. 6) and the results obtained are in agreement with the certified value Table 7.

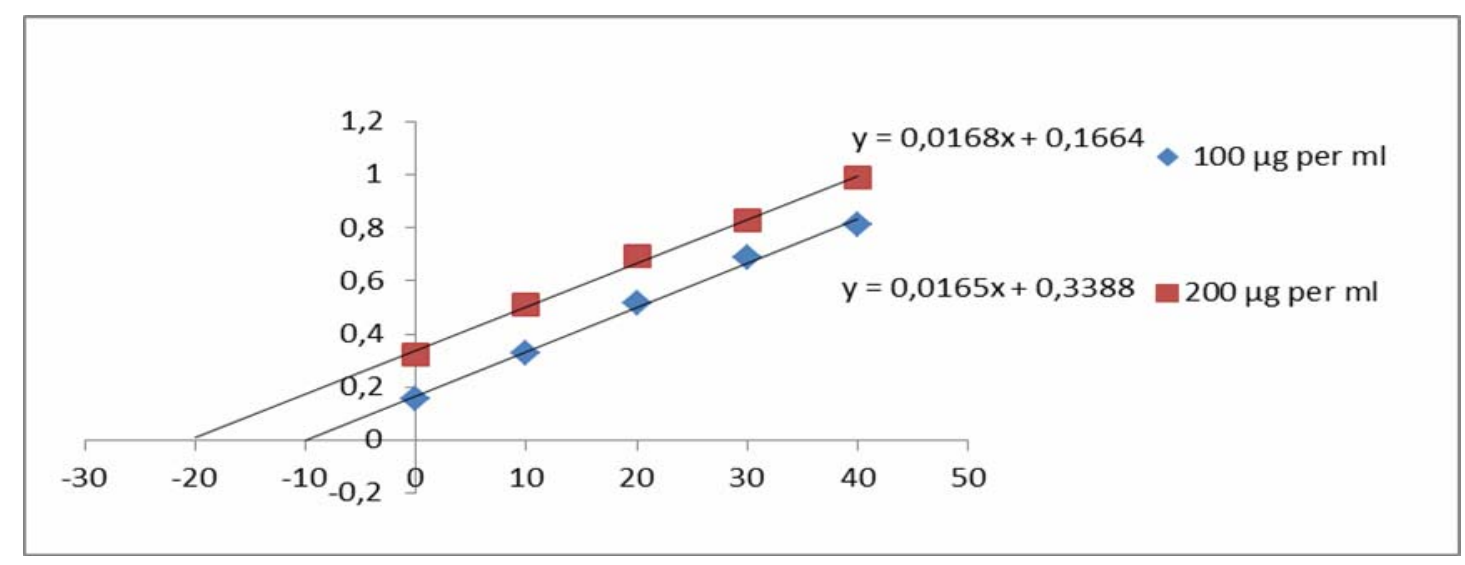

Fig.6: The plot of standard addition method 
Table 7: Result of standard addition method

\begin{tabular}{|c|c|c|c|}
\hline Pharmaceutical preparation & $\begin{array}{c}\text { Amount taken } \\
(\mu \mathrm{g})\end{array}$ & $\begin{array}{c}\text { Amount measured } \\
(\mu \mathrm{g})\end{array}$ & Recovery (\%) \\
\hline \multirow{2}{*}{$\begin{array}{c}\text { Teicoplanin Injection } \\
\text { (Targocid) }\end{array}$} & $\mathbf{1 0 0}$ & $\mathbf{9 9 . 0 5}$ & $\mathbf{9 9 . 0 5}$ \\
\cline { 2 - 4 } & $\mathbf{2 0 0}$ & $\mathbf{2 0 5 . 3 3}$ & $\mathbf{1 0 2 . 6 7}$ \\
\hline
\end{tabular}

\section{CONCLUSION}

The proposed method is simple and has a good sensitivity and it is the first proposed visible spectrophotometric method in quantitative determination of teicoplanin, it was based on coupling of teicoplanin with diazotized p-nitroaniline, reagent in alkaline medium.

\section{REFERENCE}

Al-abbasi, K. (2009). Spectrophotometric determination of tetracycline by azo dye formation with diazotized p-nitroanline - application to pharmaceutical preparation and biological fluids. J. Raf. Sci., 20, 61-74.

Barna, J.C.J.; Williams, D.H.; Stone, D.J.M.; Leung, T.W.C.; Doddrell, D.M. (1984). Structure elucidation of the teicoplanin antibiotics. J. Am. Chem. Soc., 106, 48914895.

Bourget, P.; Lesne-Hulin, A.; Sertin, A.; Maillot, A.; Alaya, M.; Martin, C. (1997). Fluorescence polarization immunoassay: Does it always represent a reliable method to monitor treatment with teicoplanin? Comparison with data obtained by highperformance liquid chromatography. Int. J. Pharmaceutics., 146(2), 167-174.

Cociglio, M.; Peyrière, H.; Hillaire-Buys, D.; Alric, R. (1998). Application of a standardized coextractive cleanup procedure to routine high-performance liquid chromatography assays of teicoplanin and ganciclovir in plasma. J. Chromatogr. $B$ Biomed. Sci. Appl.,705(1), 79-85.

Cox, H.; Whitby, M.; Nimmom, G.; Williams, G. (1993). Evaluation of a novel fluorescence polarization immunoassay for teicoplanin. J. Antimicrob. Chemother., 37(9), 1924-1926.

Hanada, K.; Kobayashi, A.; Okamor, Y.; Kimura, T.; Ogata, H. (2005). Improved quantitative determination of total and unbound concentrations of six teicoplanin components in human plasma by high performance liquid chromatography. Biol. Pharm. Bull., 28(10), 2023-5.

Hargis, L.G. (1988). "Analytical Chemistry, Principle and Techniques". Prentic-Hall, Inc., New Jersey, pp. 424-427.

http://en.wikipedia.org/wiki/File:Teicoplanin_core and major_components.svg

Joos, B.; Luthy, R. (1987). Identification of fluorescent glycopeptide derivatives by two consecutive high pressure liquid chromatographic procedures. Antibiotics XLI, (3), 302-307

Klevens, R.M.; Morrison, M.A.; Nadle, J.; Petit, S.; Gershman, K.; Ray, S.; Harrison, L.H.; Lynfield, R.; Dumyati, G.; Townes, J.M.; Craig, A.S.; Zell, E.R.; Fosheim, G.E; McDougal, L.K; Carey, R.B; Fridkin, S.K. (2007). Invasive methicillin-resistant Staphylococcus aureus infections in the United States. JAMA., 298(15),1763-71. 
McCann, S.J.; White, L.O.; Keevil, B. (2002). Assay of teicoplanin in serum: comparison of high-performance liquid chromatography and fluorescence polarization immune assay. J. Antimicrob. Chemother., 50(1), 107-10.

Othman, N.S.; Thamer, N. (2009). Spectrophotometric determination of phenylephrine hydrochloride by coupling with diazotized aminobenzothiazole. J. Raf. Sci., 20,6981 .

Taylor, R.B.; Reid, R.G. (1991). Determination of teicoplanin in plasma using microbore high-performance liquid chromatography and injection-generated gradients. $J$. Chromatogr. B. Biomed. Sci. Appl., 563(2), 451- 457.

Taylor, R.B.; Vorara, T.S.; Reid, R.G.; Boyle, S.P.; Moody, R.R. (1999). Comparisons of the separations of some neutral analytics by LC, MEKC, and CEC. J. Capill. Electrophor. Microchip. Technol., 6(3-4), 131-6.

White, L.O.; McMullin, C.; Davis, A.J.; MacGowan, A.P.; Harding, I.; Reeves, D.S. (1996). The quality of clinical serum teicoplanin assays: an experimental European EQA distribution. J. Antimicrob. Chemother., 38(4),701-706.

Wilson, A.P.; Grüneberg, R.N.; Neu, H. (1994). A critical review of the dosage of teicoplanin in Europe and the USA. Int. J. Antimicrob. Agents. (Suppl 1),1-30. 